\title{
On the Cultural Dissemination of Tao Te Ching in the Western World
}

\author{
Mei Gao \\ School of Humanities, Tiangong University, Tianjin, China \\ Email: gaomei@tjpu.edu.cn
}

How to cite this paper: Gao, M. (2020) On the Cultural Dissemination of Tao Te Ching in the Western World. Open Access Library Journal, 7: e6018.

https://doi.org/10.4236/oalib.1106018

Received: December 23, 2019

Accepted: January 10, 2020

Published: January 13, 2020

Copyright $\odot 2020$ by author(s) and Open Access Library Inc.

This work is licensed under the Creative Commons Attribution International License (CC BY 4.0).

http://creativecommons.org/licenses/by/4.0/

\begin{abstract}
Tao Te Ching not only has a profound impact on the development of Chinese civilization, but also has a profound spiritual innovation effect on western modern civilization. This thesis aims to make a study on the process of the cultural transmission of Tao Te Ching in the western world and the domestic research into it in China. It comes to the conclusion on the necessity of the research into the cultural transmission of Tao Te Ching in the west, which will promote the fusion of Chinese and western culture and the progress of human civilization.
\end{abstract}

\section{Subject Areas}

Sociology

\section{Keywords}

Cultural Dissemination, Tao Te Ching, The Western World

\section{Introduction}

Tao Te Ching, originally named Lao Tse, is a classic work of Taoist thought. With "Tao" as the core [1], it explains the origin of the universe, the developing law of things, various contradictions in human society and their solutions. It not only has a profound impact on the development of Chinese civilization, but also has a profound spiritual innovation effect on western modern civilization. Tao Te Ching is the most often translated Chinese classic in foreign languages, and it has received more and more attention in the world. Under the background of "going out of Chinese culture", the international influence of Taoist culture propagated by Tao Te Ching has become more and more evident in the western world, with the high evaluation of Tao Te Ching from domestic and foreign lite- 
rary writers and philosophers in the past two hundred years.

\section{Research Background of the Cultural Transmission of Tao Te Ching in the Western World}

According to the traditional concept, culture is not only a social phenomenon but also a historical phenomenon, which is the accumulation of human society and history. To be precise, culture is the history of a country or a nation, traditional customs, ways of life, literature and art, ways of thinking, values which can be inherited. It is a generally recognized ideology in the communications of the human beings, and it is also the sublimation of sensibility and cognition of the objective world and social experience. Research from the perspective of cultural transmission of the Chinese classic book Tao Te Ching in the western countries will help to boost the cultural confidence of the Chinese nation, and play a positive role in promoting Chinese and western cultural exchange. The study on the cultural transmission of Tao Te Ching in the western world will not only be limited to English-speaking countries, but also involve non-English-speaking countries in the western world.

\section{The Process and Tendency of the Cultural Dissemination of Tao Te Ching in the Western World}

Tao Te Ching is one of the important philosophical works and Taoist classics in ancient China. With its extensive and profound ideological and theoretical system, scholars at home and abroad have been continuously interpreting it from different perspectives.

Tao Te Ching was introduced to Japan in the Sui and Tang dynasties and Japanese scholars began to annotate and study Tao Te Ching in the Tokugawa Era. The Latin translation of Tao Te Ching by the Belgian missionary Francois Noel is considered as the beginning of the book's introduction to the western world. Then came the French translations of Tao Te Ching by the French missionary Jean Francoise Foucquet and the Sinologist Stanislas Aignan Julien. The first two German translations of Tao Te Ching by the German missionary Reinhold Von Plaenckner and the theologian V. F. Strauss started the rapid spreading of Taoist culture in the German world. Later came the Russian translations of Tao Te Ching, in which Lev Tolstoy and his assistant translated it into Russian based on the German version. The English version of Tao Te Ching has the upper hand in both quality and quantity. According to statistics, there are about 200 surviving English versions of Tao Te Ching. Among them, Arthur David Waley's English translation of Tao Te Ching and the Study on its Status in Chinese Thought is recognized as a relatively authoritative work. Later the editions of Tao Te Ching in Italian, Dutch and Swedish, etc., vividly illustrated that Tao Te Ching, which embodies Oriental culture and wisdom, had been accepted and recognized in the western world. Since the 20th century, the western world has paid more and more attention to Tao Te Ching. Philosophers and sinologists from all over the world have gradually promoted the study of Tao Te Ching to a 
higher stage.

From the trend of cultural transmission, the early western world tried its best to explain Tao Te Ching on the basis of Christianity, and the missionaries became the main force on the translation and dissemination of the Chinese Taoist culture. They interpreted the thought in Tao Te Ching from the doctrine of Christianity, which essentially advocated the rationality of Christianity, on the final purpose of defending the dominance of Christianity [2]. This reflected the superior attitude of western countries toward Chinese Taoist culture. Later, with the outbreak of the two world wars, western economy and culture were greatly damaged, and all kinds of social problems emerged. Therefore, the western philosophers began to pursue a way to solve the social and political problems from Tao Te Ching for the sake of the reconstruction of a new spiritual home. At that time western countries paid more attention to Tao Te Ching due to their own needs, which meant that they wanted to re-evaluate the western philosophical tradition from the perspective of Taoist cultural thought, and find a way out of the human dilemma caused by modern science and technology. German philosopher Georg Wilhelm Friedrich Hegel praised highly of Lao Tse's ideas, saying that Lao Tse's works, especially his Tao Te Ching, were the most admired by the world. British scientist Joseph Needham believed that Taoist thought conformed to the cognitive laws of natural science. In his 1987 State of the Union Address, President Ronald Wilson Reagan quoted one famous saying from Tao Te Ching in order to pursue a new idea on governing the country "Governing a large state is like cooking a small fish." Nowadays, with the rapid development of China's economy and the increasing of the Chinese and western economic and cultural exchange, the western countries gradually continue to spread the cultural ideological connotation of Tao Te Ching on the basis of equal interactions, and put Chinese Taoist culture and the western philosophy in the equal position, so as to seek the final unity of Chinese culture and western culture.

Tao Te Ching has been influencing various fields in the western world to varying degrees since it first went abroad. Western scholars have gradually changed their attitude towards the profound ideological and cultural connotation of Taoism in Tao Te Ching, which also increasingly illustrates the function of Tao Te Ching as the mental bridge between the east and the west.

\section{Domestic Research on the Cultural Transmission of Tao Te Ching in the Western World}

In 1997, the publication of The History of The Theory of Lao Tse initiated a comparatively systematic study on Tao Te Ching in China. The book mainly discussed the domestic study on Tao Te Ching and systematically summarized the studies and comments of the scholars in the past dynasties on Tao Te Ching [3]. With the widespread of Tao Te Ching, Chinese scholars have also begun to study the dissemination of Tao Te Ching in the western world. In 2003, Zhang Juanfang's doctoral dissertation "The Study of Lao Tse in the West in the Twen- 
tieth Century" mainly discussed the relevant studies of Tao Te Ching by scholars from English-speaking countries. In 2008, Xin Hongjuan, in her book Tao Te Ching in the English World: Text Journey and World Imagination, described the translation and dissemination of Tao Te Ching in the English world from the perspective of text translation [4], and revealed the characteristics and development process of the text translation of Tao Te Ching in the English world. There are also other related researches, but most scholars explained the dissemination and research of Tao Te Ching in English-speaking countries from the perspective of translation or literature, or from the perspective of translation in non-English speaking countries. Few scholars illustrated the influence of Tao Te Ching in the western world from the perspective of cultural transmission.

\section{Research Significance of the Cultural Dissemination of Tao Te Ching in the Western World}

Taking the cultural transmission of Tao Te Ching in the western world as the research object, and analyzing the typical translations of Tao Te Ching in the western world, we can elaborate the dissemination process and its research results and demonstrate the influence of the cultural and ideological connotation of Tao Te Ching in the west. Meanwhile, we can also summarize the different interpretations and analyses of the cultural and ideological connotations of Tao Te Ching by different scholars from different countries in different times [5], so as to reveal the law and connotation of the fusion of Chinese and western cultures during the process of the cultural transmission of Tao Te Ching in the west, which is a research issue that scholars will pay more attention to in the future.

\section{Conclusion}

The research on the cultural transmission of Tao Te Ching in the western world is still in the exploratory stage in China, and there are few systematically theoretical research findings. Most of them are concerning the study from the perspective of translation, and therefore, under the background of economic globalization in the present society, taking the cultural transmission as the breakthrough point, combined with the characteristics of the social development and diversified development trend of the world to study the cultural transmission and social acceptance of Tao Te Ching in the western world will undoubtedly improve the dialogue between Chinese and western culture, help the western countries have a thorough understanding of Chinese traditional philosophy and culture, and promote the fusion of Chinese and western culture and the common progress of human civilization.

\section{Fund}

Project of Tianjin Planning Office of Philosophy and Social Science in 2018:

"The Cultural Dissemination of Tao Te Ching in the Western World" (Project No. TJWW 18-010). 


\section{Conflicts of Interest}

The author declares no conflicts of interest regarding the publication of this paper.

\section{References}

[1] Wang, M. (1985) Studies on Taoism and Taoist Ideology. China Social Sciences Press, Beijing.

[2] Zhu, Q.Z. (1985) Influence of Chinese Philosophy on Europe. Fujian People's Publishing House, Fuzhou.

[3] Xiong, T.J. (2005) The History of The Theory of Lao Tse. Fujian People's Publishing House, Fuzhou.

[4] Xin, H.J. (2008) Tao Te Ching in the English World: Text Travel and World Imagination. Shanghai Translation Publishing House, Shanghai.

[5] Li, C. (2008) Research on Modern Theory of Lao Tse. Wuhan University Press, Wuhan. 